\title{
Quality of fresh and cryopreserved semen and their influence on the rates of fertilization, hatching and quality of the larvae of Piaractus mesopotamicus
}

\author{
J. M. Galo ${ }^{a}$, D. P. Streit-Junior ${ }^{b}$, C. A. Oliveira ${ }^{c}$, J. P. Povh ${ }^{d}$, D. C. Fornarie, \\ M. Digmayer and R. P. Ribeiro ${ }^{c}$ \\ anstituto Federal de Educação, Ciência e Tecnologia de Rondônia - IFRO, \\ Rodovia RO-257, Km 13, CEP 76878-899, Ariquemes, RO, Brasil \\ bDepartamento de Zootecnia, Universidade Federal do Rio Grande do Sul - UFRGS, \\ Av. Bento Gonçalves, 7.712, CEP 91540-000, Porto Alegre, RS, Brasil \\ 'Departamento de Zootecnia, Universidade Estadual de Maringá - UEM, \\ Av. Colombo, 5790, CEP 87030-121, Bairro Zona 07, Maringá, PR, Brasil \\ dDepartamento de Medicina Veterinária e Zootecnia, Universidade Federal de Mato Grosso do Sul - UFMS, \\ Av. Costa e Silva, CEP 79070-900, Bairro Universitário, Campo Grande, MS, Brasil \\ ${ }^{e}$ Genetic Fish Rise Consultoria e Assessoria em Piscicultura Ltda., Rod BR 163, Km 713, s/n, Primavera do Norte, \\ CEP 78890-000, Sorriso, MG, Brasil \\ *e-mail: juliana.galo@ifro.edu.br
}

Received: July 6, 2017 - Accepted: December 4, 2017 - Distributed: August 31, 2019

(With 4 figures)

\begin{abstract}
In this work, the seminal parameters of $P$. mesopotamicus were evaluated fresh and after cryopreservation, focusing on the sperm variables that affect the rates of fertilization, hatching and post-hatching parameters such as larval survival and morphology. The semen and oocytes from the animals were collected after extrusion, and seminal quality and oocyte fertilization were analyzed. Subsequently, a portion of each semen sample was cryopreserved and, after two days, the oocytes from three new females were fertilized with cryopreserved semen from the males. The analyzes showed that progressive motility, spermatic vigor, motility duration, number of normal sperm and secondary abnormalities were higher in fresh semen than in semen after thawing $(\mathrm{P}<0.0001)$. Similarly, fertilization and hatching rates and the percentage of normal and abnormal larvae in fertilized oocytes were higher when fresh semen was used $(\mathrm{P}<0.0001)$. The cryopreservation process affected the qualitative parameters of the semen of Piaractus mesopotamicus. The primary abnormality of spermatozoa was the main variable that influenced both fertilization and hatching rates, both in fresh and thawed semen. The second most important variable that influenced, particularly, thawed semen, was the spermatic vigor.
\end{abstract}

Keywords: spermatic abnormality, freezing, hatchability, spermatic vigor.

\section{Qualidade do semen fresco e criopreservado e sua influência nas taxas de fertilização, eclosão e qualidade das larvas de Piaractus mesopotamicus}

\begin{abstract}
Resumo
Neste trabalho, os parâmetros seminais de P. mesopotamicus foram avaliados fresco e após criopreservação, com foco nas variáveis espermáticas que afetam as taxas de fertilização, eclosão e os parâmetros pós-eclosão como a sobrevivência e a morfologia das larvas. Os espermatozoides e os ovócitos dos animais foram coletados após a extrusão, e a qualidade seminal e a fertilização dos ovócitos foram analisados. Posteriormente, uma porção de cada amostra de semen foi criopreservada e, após dois dias, os ovócitos de três novas fêmeas foram fertilizados com semen criopreservado dos machos. As análises mostraram que a motilidade progressiva, o vigor espermático, a duração da motilidade, o número de espermatozoides normais e anormalidades secundárias foram maiores no semen fresco do que no semen após descongelamento ( $\mathrm{P}<0,0001)$. Da mesma forma, as taxas de fertilização e eclosão e a porcentagem de larvas normais e anormais em ovócitos fertilizados foram maiores quando o semen fresco foi utilizado $(\mathrm{P}<0,0001)$. O processo de criopreservação afetou os parâmetros qualitativos do sêmen de Piaractus mesopotamicus. A anormalidade primária dos espermatozoides foi a principal variável que influenciou tanto a taxa de fertilização como a de eclosão, tanto no semen fresco como no semen descongelado. A segunda variável mais importante que influenciou, particularmente, o semen descongelado, foi o vigor espermático.
\end{abstract}

Palavras-chave: anormalidade espermática, congelação, eclodibilidade, vigor espermático. 


\section{Introduction}

Piaractus mesopotamicus, popularly known as "pacu", is a large fish intensively used in aquaculture and for repopulation of hydroelectric reservoirs in Brazil. The production of this species has increased because of its high commercial value and acceptance in national market (Maria et al., 2004). Although P. mesopotamicus is easily adapted to fishculture, natural breeding in captivity is unfeasible, thus requiring hormonal induction (Romagosa et al., 1988).

The cryopreservation of gametes is regarded as an important tool for the fry production in laboratories once it optimizes the broodstock utilization and avoids the loss of genetically improved lineages. This technique also facilitates the interchange of genetic material between facilities by transportation of frozen sperm, thus preventing the transmission of diseases and allowing the introduction of new lineages with minimized risks of pathogens in the raised fish (Tiersch, 1995; Viveiros and Godinho, 2009).

Over the last years, the gamete preservation of Brazilian native species, like Brycon orbignyanus (Maria et al., 2006), P. mesopotamicus (Streit-Junior et al., 2007) and Salminus maxillosus (Streit-Junior et al., 2008) has been prioritized due to their economical and environmental relevance. Therefore, the application of basic knowledge that yields a successful reproduction and growth at captivity as well as the development of conservation techniques in these species is essential.

The ability of freezing and thawing spermatozoa depends on several features such as: species, individual traits and reproductive period (Bromage and Roberts, 1995). Studies about seminal quality in fish have shown individual variation in several parameters like motility and sperm concentration, besides their ability to fertilize and storage (Rana, 1995). According to Bromage and Roberts (1995), the successful fertilization is the ultimate test to evaluate the semen quality, being widely used in artificial breeding and sperm conservation.

Another major parameter in the evaluation of seminal quality is the morphology of spermatic cells. Indeed, Lahnsteiner et al. (1998) and Cosson et al. (1999) reported that increased abnormalities cause reduction of spermatic motility, potentially decreasing the fertilization rate. However, the semen pathologies examined in fish with views to large-scale production are particularly restricted to structural changes in spermatozoa after cryopreservation (Yao et al., 2000; Taddei et al., 2001) while their effects on fertilization and hatching rates remain overlooked. Therefore, the goal of the present study was to evaluate fresh and post-cryopreservation seminal parameters of $P$. mesopotamicus, with emphasis on the variables affecting fertilization and hatching rates as well as the larval survival and morphology.

\section{Material and Methods}

\subsection{Locality}

The experiment was carried out in the aquaculture facility at Duke Energy Brazil, in Salto Grande (SP) by the staff research members from PeixeGen at Universidade
Estadual de Maringá (UEM) and Aquam at Universidade Federal do Rio Grande do Sul (UFRGS).

\subsection{Semen collection and analysis}

Six males and six females of $P$. mesopotamicus from captivity, presenting secondary reproductive traits of rheophilic fish, were selected, weighed and labeled with microchip for individual identification. The animals were fed with a commercial ration containing $36 \%$ crude protein and $2,900 \mathrm{kcal}$ of digestible energy $/ \mathrm{kg}$ of ration.

During the reproductive period, the semen was obtained by inducting the males with extract of pituitary hormone from carp (PHC; 5.5 and $2.5 \mathrm{mg}$ PHC/kg fishes, females and males, respectively). After hormonal induction, the semen was collected into $5 \mathrm{~mL}$ syringes (Billard et al., 1994). The chemicals were procured from Sigma Aldrich, St. Louis, MO, USA. The methods employed in evaluation of seminal parameters are described below:

- Motility and Spermatic vigor: A total of $20 \mu \mathrm{L}$ of semen was diluted into $200 \mu \mathrm{L}$ of distilled water on a microscopy glass slide, which was covered with a coverslip and both variables were immediately analyzed under optic microscope (40X). The motility score ranged from 0 to $100 \%$ and spermatic vigor was scored from 0 to 5 points.

- Duration of motility: A chronometer was started when $20 \mu \mathrm{L}$ of semen was placed into $200 \mu \mathrm{L}$ of distilled water onto a microscope glass slide. The time spent up to the last spermatozoon had stopped moving in the optical field (40X) was noted.

- Spermatic concentration: The semen was diluted in buffered saline formaldehyde at 1:1000 proportion in a Becker and the solution was homogenized and used to fill the Neubauer's chamber by capillarity for counting spermatozoa and evaluation of spermatic concentration.

- Spermatic morphology: For this analysis a smear was produced with the semen diluted in buffered saline formaldehyde, in the ratio of 1:1000 (semen/diluent solution, respectively). The smears were stained by the Rose Bengal method (Streit-Junior et al., 2004), and after drying, taken under an optical microscope with $40 \mathrm{X}$ objective, counting 150 spermatozoa per smear of each animal. Primary abnormalities included: broken, curled and degenerated tails, and secondary abnormalities: bent tail, loose head and loose tail.

\subsection{Sperm cryopreservation}

One aliquot of each collected sample was cryopreserved in dilutors as proposed by (Carolsfeld et al., 2003) for rheophilic fish. The semen and the cryoprotectant solution were homogenized at a proportion of 1:3 of semen:solution, and placed into palettes $0.25 \mathrm{~mL}$ and then deposited in a dry shipper container (model DOUBLE 20). After 15 hours, the palettes were transferred to a storage container with 
liquid nitrogen at $-196{ }^{\circ} \mathrm{C}$. After 48 hours, the semen was thawed for five seconds at $45^{\circ} \mathrm{C}$, and the progressive motility, spermatic vigor, duration of motility and spermatic morphology were evaluated.

\subsection{Fertilization and hatching rates and larval morphology}

To compare the fertilizing ability of spermatozoa, oocytes of three females were mixed into fresh semen of six males. Two days later, the same but cryopreserved sperm was mixed into oocytes of three other females. These three spawns fertilized with the semen of each animal from both moments (fresh and after cryopreservation) were divided into six aliquots, totalizing 18 combinations (oocytes $\times$ fresh semen) and 18 combinations (oocytes $\times$ cryopreserved semen). For fertilization of fresh semen, $10 \mathrm{~mL}$ of oocyte for female were used for each $0.5 \mathrm{~mL}$ of semen from each male. For the cryopreserved semen, $10 \mathrm{~mL}$ of oocytes from each female were used for $1.0 \mathrm{~mL}$ of semen from each male. The ratio of spermatozoa per oocyte was $780 \times 10^{3}$ for fresh semen and $515 \times 10^{3}$ for cryopreserved semen, following the recommendations of Leite et al. (2013) and Galo et al. (2011).

After fertilization, the eggs were placed into $7 \mathrm{~L}$ incubators, individualized for each combination, and the fertilization rate was established after seven hours of incubation $\left(T=26 \pm 1^{\circ} \mathrm{C}\right)$. One aliquot from each incubator was removed using a hose, and placed onto a Petri dish for counting of viable eggs. This step was performed three times, resulting in 100 counted eggs per sample, on average. From this total, the mean was calculated to obtain the fertilization rate.

To calculate the hatching rate, 100 viable embryos from each $7 \mathrm{~L}$ incubator were transferred to $1.5 \mathrm{~L}$ incubators. After 18 hours of fertilization with a mean water temperature of $26 \pm 1{ }^{\circ} \mathrm{C}$, the hatching rate was determined in $7 \mathrm{~L}$ incubators. To obtain the hatching rate of $1.5 \mathrm{~L}$ incubators, all unviable eggs and larvae were removed and counted to determined the percentage of: normal larvae (regular movement); abnormal larvae (movement disabilities or abnormal notochord); dead larvae (hatched larvae that were dead at the moment of counts); unviable eggs, non hatched larvae (incompletely hatched larvae that were alive during counts) and non hatched dead larvae (incompletely hatched larvae that were dead during counts).

\subsection{Scanning Electron Microscopy (SEM) of spermatozoa and larvae}

One $\mu \mathrm{L}$ of fresh semen and $50 \mu \mathrm{L}$ of frozen semen were fixed in $999 \mu \mathrm{L}$ and $950 \mu \mathrm{L}$ of $2.5 \%$ glutaraldehyde solution with $0.1 \mathrm{M}$ cacodylate buffer in $\mathrm{pH} 7.2$ and stored at $5{ }^{\circ} \mathrm{C}$ up to dehydration. Afterwards, the samples were centrifuged at $10000 \mathrm{rpm}$ for 3 minutes and washed three times in cacodylate buffer. The dehydration was performed using an increasing ethanol series at concentrations of $50,70,80,90$ and $95 \%$ for 10 minutes in each step, followed by three baths in $100 \%$ ethanol for 10 minutes. The samples was dried in a critical point dryer (BAL-TEC CPD 030), using liquid $\mathrm{CO}_{2}$. The fragments were mounted in aluminum stubs and metalized with gold-palladium ions in a metalizer Shimadzu IC 50 Ion Coater.

The fixation of each larva was performed using $2.5 \%$ glutaraldehyde solution and $0.1 \mathrm{M}$ cacodylate buffer in

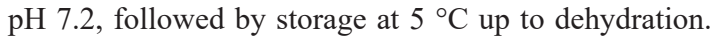
The dehydration took place at room temperature in cell culture plates during 48 hours. The fragments were mounted in aluminum stubs and metalized with gold-palladium ions in a metalizer Shimadzu IC 50 Ion Coater.

For SEM procedures, the material was examined and electronmicrographed using a scanning electron microscope Shimadzu SS 550 Superscan from the Complexo Central de Apoio a Pesquisa (COMCAP/UEM).

\subsection{Statistical analysis}

The statistical analysis was performed using the Proc GLM from SAS, in order to evaluate the effect of treatment (fresh and frozen semen) over the variables (progressive motility, spermatic vigor, duration of motility, spermatic concentration, normal spermatozoa, primary and secondary abnormalities).

To characterize the effects of treatments, the principal component analysis was performed for each treatment level using the Proc PRINCOMP from SAS.

\section{Results}

\subsection{Quali-quantitative semen parameters}

The spermatic concentration ranged from $14.35 \times 10^{9}$ to $28.65 \times 10^{9}$ spermatozoa $\mathrm{mL}^{-1}$, with a mean value of $21.09 \times 10^{9}$ spermatozoa $\mathrm{mL}^{-1}$.

As for the seminal parameters evaluated, the progressive motility, duration of motility and spermatic vigor were higher for fresh semen $(\mathrm{P}<0.0001)$ than in thawed semen (Table 1).

Table 1. Progressive motility, duration of motility, spermatic vigor and spermatic morphology of fresh and thawed sperm of P. mesopotamicus.

\begin{tabular}{lcc}
\hline \multicolumn{1}{c}{ Parameters } & \multicolumn{2}{c}{ Semen } \\
\cline { 2 - 3 } & \multicolumn{1}{c}{ Fresh } & Thawed \\
\hline $\begin{array}{l}\text { Progressive motility } \\
(\%)\end{array}$ & $90.83 \pm 7.32 \mathrm{a}$ & $11.83 \pm 7.41 \mathrm{~b}$ \\
$\begin{array}{l}\text { Duration of motility } \\
\text { (sec.) }\end{array}$ & $42.03 \pm 8.85 \mathrm{a}$ & $31.72 \pm 7.11 \mathrm{~b}$ \\
$\begin{array}{l}\text { Spermatic vigor } \\
\text { (points) }\end{array}$ & $4.83 \pm 0.42 \mathrm{a}$ & $3.17 \pm 0.38 \mathrm{~b}$ \\
$\begin{array}{l}\text { Normal spermatozoa } \\
(\%)\end{array}$ & $50.11 \pm 7.26 \mathrm{a}$ & $35.39 \pm 4.48 \mathrm{~b}$ \\
$\begin{array}{l}\text { Total abnormalities } \\
\text { (\%) }\end{array}$ & $49.89 \pm 7.26 \mathrm{~b}$ & $64.61 \pm 4.48 \mathrm{a}$ \\
$\begin{array}{l}\text { Primary } \\
\text { abnormalities (\%) }\end{array}$ & $42.52 \pm 6.26 \mathrm{~b}$ & $71.86 \pm 5.43 \mathrm{a}$ \\
$\begin{array}{l}\text { Secondary } \\
\text { abnormalities (\%) }\end{array}$ & $57.48 \pm 5.05 \mathrm{a}$ & $28.14 \pm 3.81 \mathrm{~b}$ \\
\hline
\end{tabular}

Means in the same line with the same letter had no significant differences; $\mathrm{sec}$ - seconds. 


\subsection{Spermatic morphology: fresh and thawed semen}

The percentage of normal spermatozoa was lower in the thawed semen $(\mathrm{P}<0.0001)$, consequently causing a higher proportion of total abnormalities in the cryopreserved semen $(\mathrm{P}<0.0001)$. The freezing process increased the index of primary abnormalities from $42.52 \%$ (fresh) to $71.86 \%$ (thawed semen) (Table 1). On the other hand, the secondary abnormalities remained higher $(\mathrm{P}<0.0001)$ in fresh semen $(57.48 \%)$ than in thawed semen $(28.14 \%)$.

The number of spermatozoa with curled (Figure 1F) and detached tail (Figure 1E) had no differences $(\mathrm{P}>0.05)$ between fresh and thawed semen. It was observed that spermatozoa bearing degenerate tails (Figure 2D) $(\mathrm{P}<0.0001)$, broken tails (Figure 1B) $(\mathrm{P}<0.05)$ and detached head (Figure 1E) $(\mathrm{P}<0.05)$ increased in the semen after thawing. However, the bent tail abnormality (Figure 1D) was higher in fresh semen $(\mathrm{P}<0.0001)$ than in thawed sperm (Figure 3$)$.

\subsection{Fertilization and hatching rates and post-hatching parameters}

The mean fertilization and hatching rates were higher $(\mathrm{P}<0.0001)$ when fresh semen was used in relation to thawed sperm. As for the morphology of hatched larvae, differences were observed in the number of normal larvae $(\mathrm{P}<0.001)$, unviable eggs $(\mathrm{P}<0.001)$ and abnormal larvae $(\mathrm{P}<0.001)$, with a higher percentage in fresh than in thawed semen. On the other hand, the proportion of dead larvae,

and non-hatched dead and living larvae presented no differences $(\mathrm{P}>0.05)$ when oocytes were fertilized with fresh or thawed sperm (Table 2).

Both normal and abnormal larvae obtained from fresh and thawed semen of $P$. mesopotamicus are shown in Figure 4.

Table 2. Fertilization and hatching rates, percentages of unviable eggs, normal, abnormal, dead, non-hatched dead and non-hatched living larvae using fresh and thawed sperm of $P$. mesopotamicus.

\begin{tabular}{ccc}
\hline Parameters & Fresh semen & Thawed semen \\
\hline $\begin{array}{c}\text { Fertilization rate } \\
(\%)\end{array}$ & $95.64 \pm 1.70 \mathrm{a}$ & $59.01 \pm 25.69 \mathrm{~b}$ \\
Hatching rate $(\%)$ & $92.31 \pm 7.93 \mathrm{a}$ & $37.34 \pm 23.28 \mathrm{~b}$ \\
Unviable eggs & $0.23 \pm 0.54 \mathrm{~b}$ & $44.32 \pm 37.22 \mathrm{a}$ \\
$(\%)$ & & \\
Normal larvae & $52.15 \pm 31.16 \mathrm{a}$ & $13.25 \pm 17.15 \mathrm{~b}$ \\
$(\%)$ & & \\
$\begin{array}{c}\text { Abnormal larvae } \\
(\%)\end{array}$ & $24.45 \pm 16.68 \mathrm{a}$ & $8.01 \pm 9.90 \mathrm{~b}$ \\
$\begin{array}{c}\text { Dead larvae }(\%) \\
\text { Non hatched dead } \\
\text { larvae }(\%)\end{array}$ & $3.81 \pm 7.74 \mathrm{a}$ & $6.49 \pm 8.95 \mathrm{a}$ \\
$\quad \begin{array}{l}\text { Non hatched } \\
\text { living larvae }(\%)\end{array}$ & $1.28 \pm 2.79 \mathrm{a}$ & $0.05 \pm 0.23 \mathrm{a}$ \\
\hline $\begin{array}{l}\text { Means in the same line with the same letter had no significant } \\
\text { differences. }\end{array}$ &
\end{tabular}
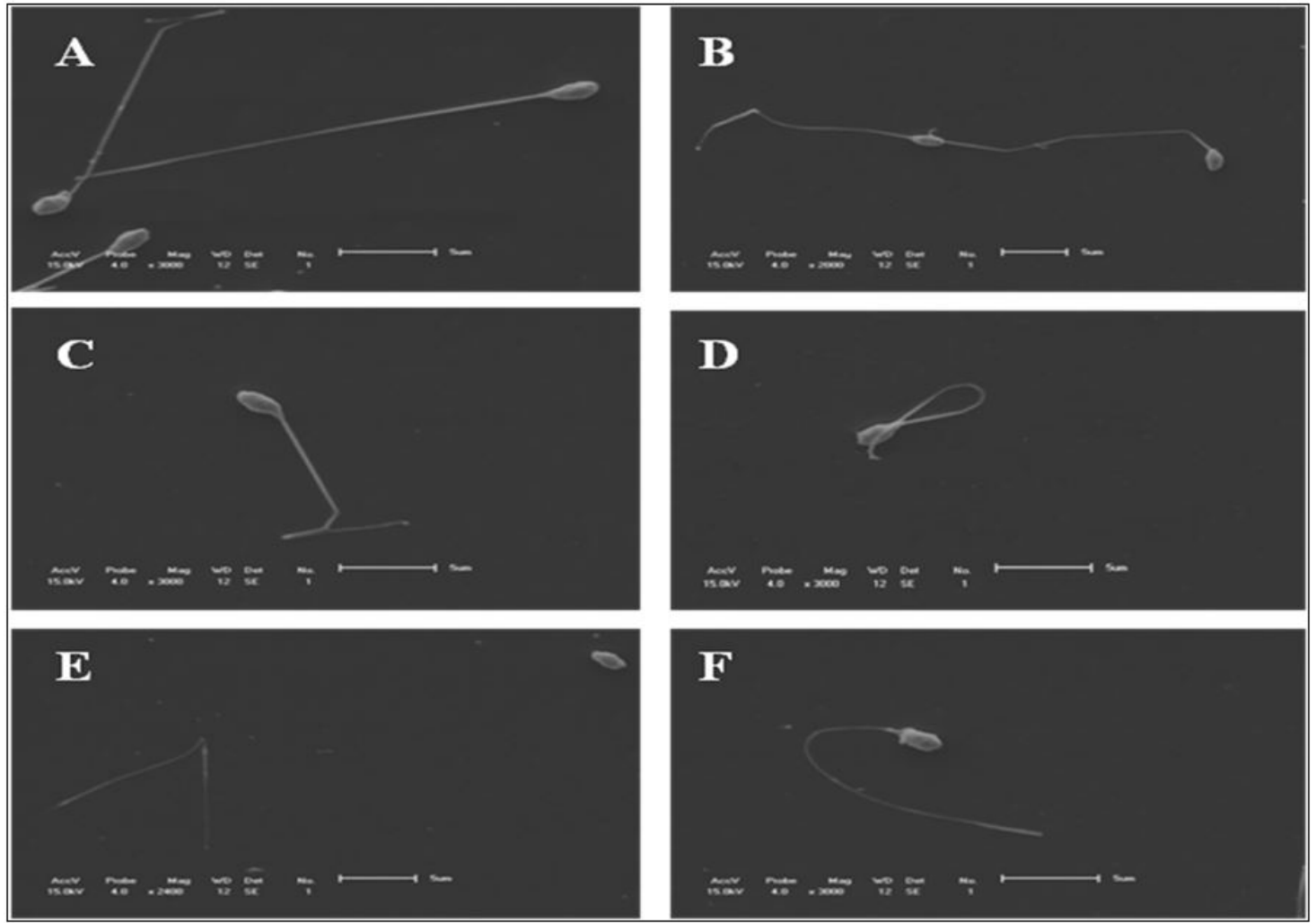

Figure 1. Illustrations of morphologies obtained of fresh spermatozoa of $P$. mesopotamicus by SEM. (A) normal spermatozoa; (B) broken tail; (C) curled and broken tail; (D) bent tail; (E) detached head and tail; (F) curled tail. 

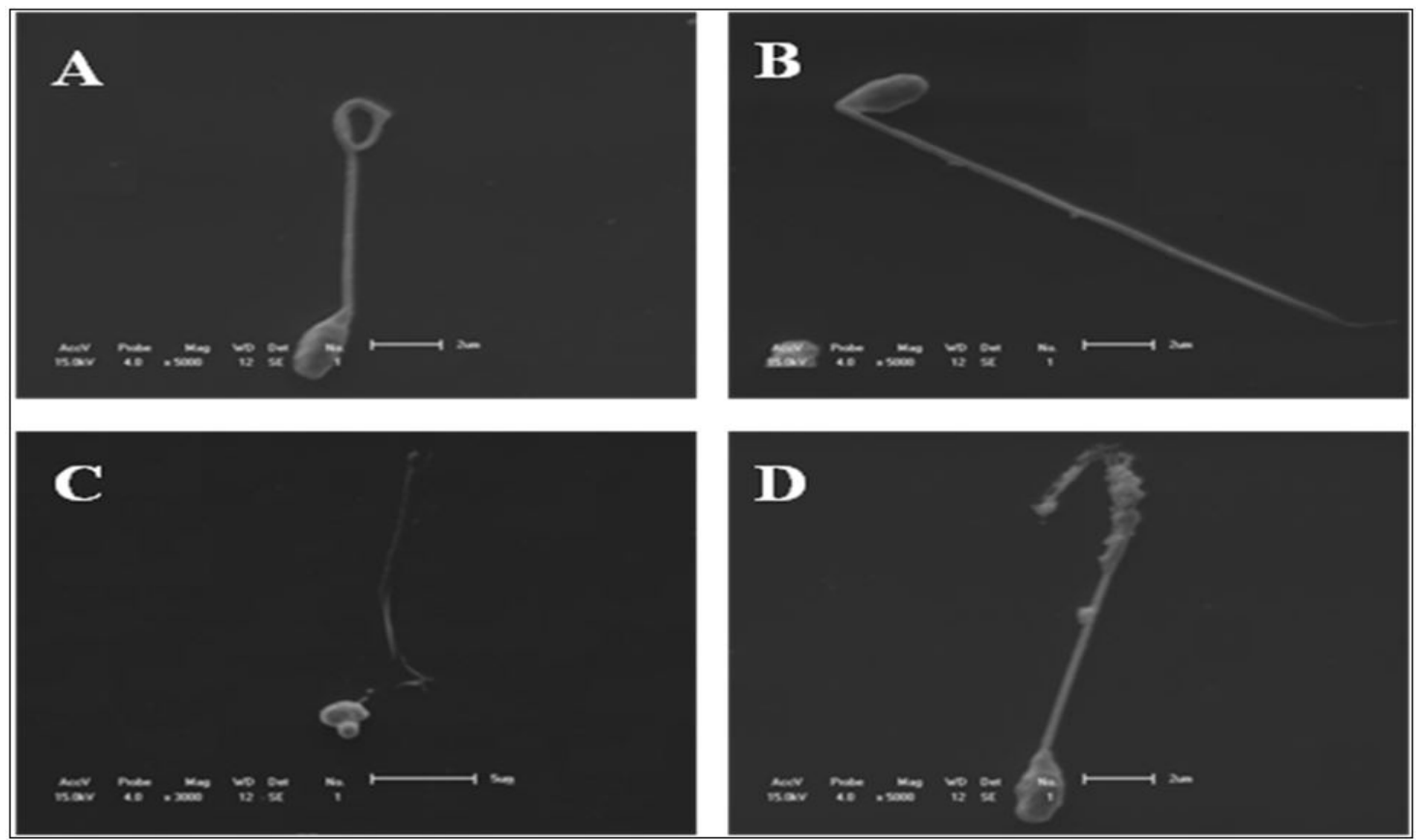

Figure 2. Illustrations of morphologies obtained of cryopreserved spermatozoa of $P$. mesopotamicus by SEM. (A) curled tail; (B) broken tail; (C) and (D) degenerated tail.

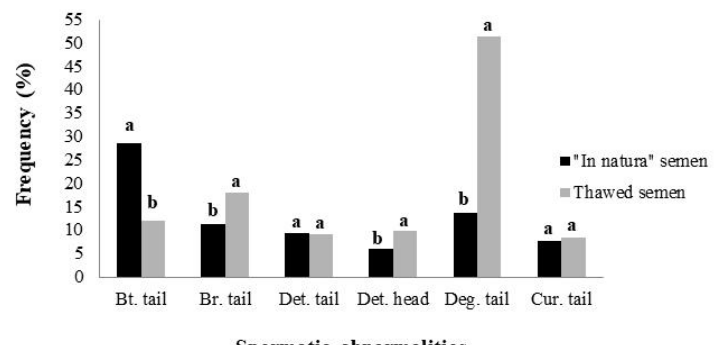

Spermatic abnormalities

Figure 3. Mean percentage of abnormalities found in thawed and fresh semen of P. mesopotamicus. Bent tail (Bt. tail); broken tail (Br. tail); detached tail (Det. tail); detached head (Det. head); degenerated tail (Deg. tail); curled tail (Cur. tail).

\subsection{Principal components - variables that influences the fertilization and hatching rates}

The Principal Component Analysis (PCA) indicated that about $87 \%$ of total variation of fresh semen could be explained by three components. The primary abnormality was the most relevant variable for the first principal component (52.2\%). The set of variables such as secondary abnormalities (49.4\%), total abnormalities (44.2\%), normal spermatozoa (44.2\%), duration of motility (43.7\%) and spermatic motility (38.7\%), presented a higher importance in the second principal component. About $75.6 \%$ of the third component was explained by the variable "spermatic concentration", indicating its higher relevance to determine this component.
Likewise, three principal components were observed in the thawed, which explained $97.66 \%$ of total variation. As observed with fresh semen, the primary abnormality was the variable with the highest score (47\%) in the first principal component. Two other variables, spermatic vigor and secondary abnormalities, composed the second principal component (49.8\% and 54\%, respectively). In contrast with fresh semen, the third principal component in thawed sperm referred to duration of motility $(58.6 \%)$.

\section{Discussion}

The mean spermatic concentration value herein observed in semen of $P$. mesopotamicus corroborates the reports by Silveira et al. (1990) of $28.07 \times 10^{9}$ spermatozoa $\mathrm{mL}^{-1}$ and Miliorini et al. (2002), of $18.62 \times 10^{9}$ spermatozoa $\mathrm{mL}^{-1}$ in this species. On the other hand, (Maria et al., 2004) reported a mean concentration of $13.89 \times 10^{9}$ spermatozoa $\mathrm{mL}^{-1}$ in pacu, what was related to the reproductive stage of males during semen collection.

It is certain that the freezing process of semen causes injuries in both tail and head of spermatozoa. However, the origin of such abnormalities is usually determined by the temperature reduction or to the exposure to toxicity of cryoprotectant solution. The increased spermatic abnormalities like broken and degenerated tails after thawing of $P$. mesopotamicus semen might be explained as proposed by Taddei et al. (2001), in studies with Diplodus puntazzo. These authors suggested that cell osmoregulation can be damaged when spermatozoa are exposed to cryoprotectant solutions, resulting in enlargement of head or tail, followed 

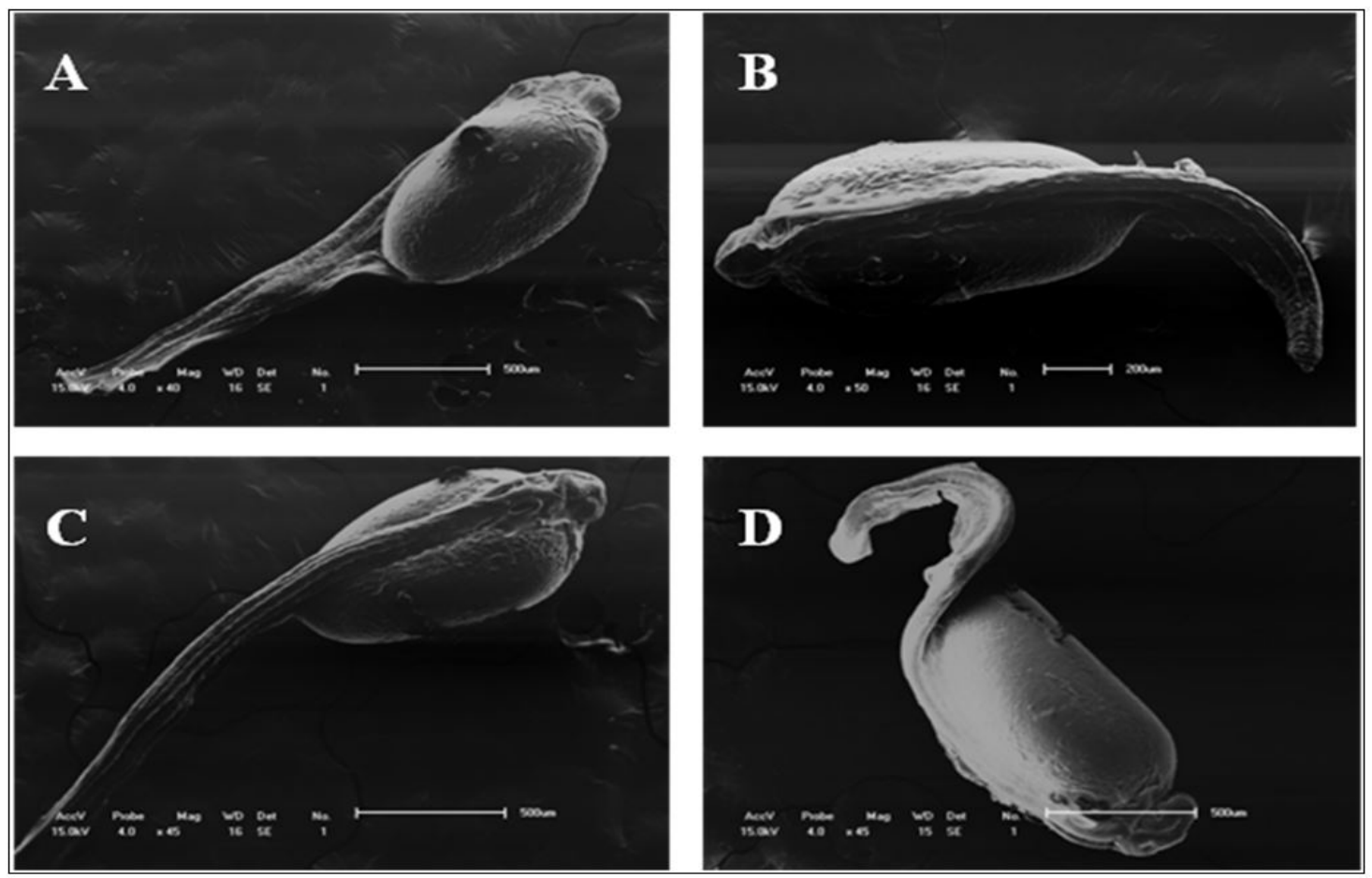

Figure 4. Larval morphology of $P$. mesopotamicus after fertilization using fresh and thawed semen as observed in SEM. (A) normal larva - fresh semen; (B) abnormal lava - fresh semen; (C) normal larva - thawed semen; (D) abnormal lava - thawed semen.

by injuries in intracellular organelles. According to these authors, this scenario may lead to dysfunction of mitochondria and effusion of nuclear chromatin, giving rise to abnormal or dead spermatic cells. Kavamoto et al. (1999) observed that morphological abnormalities of midpiece and tail cause progressive alterations in motility, increasing the number of spermatozoa with circular or oscillatory movements thereby reducing the fertilization rate.

In the present work, the qualitative indexes reported for progressive motility, spermatic vigor and duration of motility reinforce the loss of semen quality after thawing, in agreement with the findings of Streit-Junior et al. (2006), in the same species. Therefore, we can assume that the structural malformations in spermatozoa of $P$. mesopotamicus took place during freezing and thawing processes, thus decreasing the qualitative values of abovementioned parameters (progressive motility, spermatic vigor and duration of motility). The correlation between these traits is stressed out by Taddei et al. (2001), who reported that frequently frozen spermatozoa presented a several enlargement or partial loss of mitochondria in the midpiece, besides broken tails. During cryopreservation, the mitochondria might be damaged or pushed away from the midpiece because of the swelling of the latter. According to Zhang et al. (2003), these changes can severely affect both mitochondrial and tail function, reducing the flagellum movement of spermatozoa and, consequently, determining their loss of motility abilities.
The decreased values in qualitative parameters (motility, spermatic vigor and duration of motility) caused by changes in the structural morphology of spermatozoa (primary abnormalities) in thawed semen explains the reduced fertilization and hatching rates observed in P. mesopotamicus. This statement is supported by the principal component analysis, since $97.66 \%$ of the fertilization rate is explained by four variables, being the primary abnormality the most important one. The report by Yao et al. (2000) after cryopreservation of semen of ocean pout (Macrozarces americanus) can be possibly applied to our work; these authors identified a drastic enlargement over mitochondria and/or dehydration of cytoplasm in midpiece of spermatozoa, suggesting that alterations in mitochondrial activity depleted the energy supplies of spermatic cells, leading to reduction of flagella movements and eventually to the loss of progressive motility.

Although the spermatic quality decreased after cryopreservation in the present study, mainly related to losses in spermatic motility, the proper fertilization rate observed might be related to the high vigor (3.17 points) of spermatic cells. This inference is corroborated by the principal component analysis, since the spermatic vigor was a major variable in the second principal component in thawed semen, differing from the pattern observed for fresh semen. In spite of their reduced motility, the spermatozoa that remained viable after thawing probably had no damages in the midpiece. 
The toxicity of cryoprotectants and the inefficiency of cryopreservation process are referred by Fabbrocini et al. (2000), as the main causes of injuries on spermatic cells. Another major factor is mentioned by Miliorini et al. (2011) that highlighted the importance of the knowledge about the level of abnormalities in semen to determine the spermatozoa. oocyte $^{-1}$ ration. The principal component analysis of P. mesopotamicus semen revealed that primary abnormalities were the main variable affecting fertilization and hatching rates in both fresh and thawed semen, reinforcing the negative influence hypothesized for this parameter.

Miliorini et al. (2011) analyzing frozen semen of $P$. lineatus reported about $28 \%$ of total abnormalities in frozen semen with DMSO, with a fertilization rate of $37 \%$. In this study, the fertilization rate was equal to $59 \%$ for thawed semen using the same cryoprotectant, although a higher percentage of abnormalities (96.4\%) was also observed in relation to these authors. On the other hand, Streit-Junior et al. (2009) studying cryopreserved semen of $P$. mesopotamicus reported $54.6 \%$ of primary abnormalities, $23 \%$ of motility and 2.3 points of spermatic vigor, corroborating the results from the present study, which comprised $46.4 \%$ of primary abnormalities, $11.8 \%$ of motility and 3.1 points of spermatic vigor, and demonstrating the importance of the latter during the freezing/thawing process. The cryopreservation affected the qualiquantitative parameters in the semen of $P$. mesopotamicus. The percentage of primary abnormalities in spermatozoa is the main variable influencing both fertilization and hatching rates in either fresh or thawed semen. Similarly, the spermatic vigor was also important during the freezing/thawing process.

\section{References}

BILLARD, R., COSSON, J., CRIM, L.W. and SUQUET, M., 1994. Broodstock management and seed quality-general considerations. In: N. BROMAGE and R.J. ROBERTS, eds. Broodstock management and egg larval quality. Oxford: Blackwell Science, pp. 1-24.

BROMAGE, N.R. and ROBERTS, R.J., 1995. Broodstock management and egg and larval quality. Oxford: Blackwell Science.

CAROLSFELD, J., GODINHO, H.P., ZANIBONI FILHO, E. and HARVEY, B.J., 2003. Cryopreservation of sperm in brazilian migratory fish conservation. Journal of Fish Biology, vol. 63, no. 2, pp. 472-489. http://dx.doi.org/10.1046/j.1095-8649.2003.00170.x.

COSSON, J., BILLARD, R., CIBERT, C., DREANNO, C. and SUQUET, M., 1999. Ionic factors regulating the motility of fish sperm. In: C. GAGNON, ed. The male gamete: from basic science to clinical applications. Viena: Cache River Press, pp. 162-186.

FABBROCINI, A., LAVADERA, S.L., RISPOLI, S. and SANSONE, G., 2000. Cryopreservation of seabream (Sparus aurata) spermatozoa. Cryobiology, vol. 40, no. 1, pp. 46-53. http:// dx.doi.org/10.1006/cryo.1999.2220. PMid:10679149.

GALO, J.M., STREIT-JUNIOR, D.P., RIBEIRO, R.P., URIBE, L., RESENDE, E.K., GUERREIRO, L.R.J., OLIVEIRA, D., GARCIA, R., MORAES, G.V. and OBERST, E.R., 2011. Dose inseminante para fertilização artificial de ovócitos de Colossoma macropomum. In: Anais da III Conferência Latinoamericana sobre cultivo de peixes nativos e III Congresso Brasileiro de Produção de Peixes Nativos; 13-15 Julho 2011; Lavras. Lavras: Naqua, UFLA. pp. 320.

KAVAMOTO, E.T., BARNABE, V.H. and CAMPOS, B.E.S., 1999. Anormalidades morfológicas nos espermatozoides do curimbatá Prochilodus lineatus (Steindachner, 1881) (Osteichthyes, Characiformes, Prochilodontidae). Boletim Instituto de Pesca, vol. 25, pp. 61-66.

LAHNSTEINER, F., BERGER, B., WEISMANN, T. and PATZNER, R.A., 1998. Determination of semen quality of the rainbow trout Oncorhynchus mykiss by sperm motility, seminal plasma parameters, and spermatozoa metabolism. Aquaculture, vol. 163, no. 1-2, pp. 163-181. http://dx.doi.org/10.1016/S00448486(98)00243-9.

LEITE, L.V., MELO, M.A.P., OLIVEIRA, F.C.E., PINHEIRO, J.P.S., CAMPELLO, C.C., NUNES, J.F. and SALMITOVANDERLEY, C.S.B., 2013. Determinação da dose inseminante e embriogênese na fertilização artificial de tambaqui (Colossoma macropomum). Arquivo Brasileiro de Medicina Veterinária e Zootecnia, vol. 65, no. 2, pp. 421-429. http://dx.doi.org/10.1590/ S0102-09352013000200018.

MARIA, A.N., MURGAS, L.D.S., SILVA, M.O.B., MILIORINI, A.B., FRANCISCATTO, R.T. and LOGATO, P.V.R., 2004. Influência da adição de iodeto de potássio e citrato de sódio na qualidade do sêmen de pacu (Piaractus mesopotamicus Holmberg, 1887). Ciência e Agrotecnologia, vol. 28, no. 1, pp. 191-194. http://dx.doi.org/10.1590/S1413-70542004000100025.

MARIA, A.N., VIVEIROS, A.T.M., FREITAS, R.T.F. and OLIVEIRA, A.V., 2006. Extenders and cryoprotectants for cooling and freezing of piracanjuba (Brycon orbignyanus) semen, an endangered Brazilian teleost fish. Aquaculture, vol. 260, no. 1-4, pp. 298-306. http://dx.doi.org/10.1016/j.aquaculture.2006.06.011.

MILIORINI, A.B., MURGAS, L.D.S., ROSA, P.V., OBERLENDER, G., PEREIRA, G.J.M. and COSTA, D.V., 2011. A morphological classification proposal for curimba (Prochilodus lineatus) sperm damages after cryopreservation. Aquaculture Research, vol. 42, no. 2, pp. 177-187. http://dx.doi.org/10.1111/j.1365-2109.2010.02575.x.

MILIORINI, A.B., MURGAS, L.D.S., VIVEIROS, A.T.M., FRANCISCATTO, R.T., SILVA, M.O.B. and MARIA, A.N., 2002. Resfriamento do sêmen de pacu (Piaractus mesopotamicus) à $4{ }^{\circ} \mathrm{C}$, utilizando diferentes concentrações de dimetilsulfóxido. Revista Brasileira de Reprodução Animal, vol. 26, pp. 209-211.

RANA, K., 1995. Preservation of gametes. In: N.R. BROMAGE and R.J. ROBERTS, eds. Broodstock management and egg and larval quality. Hoboken: Blackwell Science, pp. 424.

ROMAgosA, E., PAIVA, P., GODinhO, H.M., 1988. Desenvolvimento dos ovócitos de Piaractus mesopotamicus (Holmberg, 1887) (Colossoma mitrei Berg, 1895) em condições de cultivo intensivo. Ciência e Cultura, vol. 40, no. 1, pp. 60-63.

SILVEIRA, W.F., KAVAMOTO, E.T., CESTAROLLI, M.A., GODINHO, H.M., RAMOS, S.M. and SILVEIRA, A.N., 1990. Avaliação espermática, preservação criogênica e fertilidade do sêmen do pacu, Piaractus mesopotamicus (Holmberg, 1887), proveniente de reprodução induzida. Boletim Instituto de Pesca, vol. 17, pp. 1-13.

STREIT-JUNIOR, D.P., BENITES, C., MORAES, G.V., RIBEIRO, R.P., SAKAGUTI, E.S. and CALDIERI, R.F., 2006. Sêmen de pacu (Piaractus mesopotamicus) criopreservado com diluentes utilizados para sêmen de suínos. Ciência Animal Brasileira, vol. 7, no. 3, pp. 289-297. 
STREIT-JUNIOR, D.P., MORAES, G.V., RIBEIRO, R.P., POVH, J.A., SOUZA, E.D. and OLIVEIRA, C.A.F., 2004. Avaliação de diferentes técnicas para coloração de sêmen de peixes. Arquivos de Ciências Veterinárias e Zoologia da UNIPAR, vol. 7, pp. 157-162.

STREIT-JUNIOR, D.P., OLIVEIRA, A.C., RIBEIRO, R.P., SIROL, R.N., MORAES, G.V., GALO, J.M. and DIGMAYER, M., 2009. Motilidade, vigor e patologia seminal in natura e pós criopreservação de Piaractus mesopotamicus. Boletim Instituto de Pesca, vol. 35, pp. 159-167.

STREIT-JUNIOR, D.P., RIBEIRO, R.P., MORAES, G.V., VARGAS, L.D.M., DIGMAYER, M., GALO, J.M., POVH, J.A., BRACCINI NETO, J., 2007. Sêmen de pacu (Piaractus mesopotamicus) submetido ao resfriamento ao longo do tempo com diferentes meios diluidores. Revista Biociências, vol. 13, no. 3-4, pp. 178-187.

STREIT-JUNIOR, D.P., SIROL, R.N., RIBEIRO, R.P., MORAES, G.V., GALO, J.M. and DIGMAYER, M., 2008. Parâmetros qualitativos do sêmen de dourado (Salminus maxillosus) em cativeiro. Boletim Instituto de Pesca, vol. 34, no. 3, pp. 337-344.

TADDEI, A.R., BARBATO, F., ABELLI, L., CANESE, S., MORETTI, F., RANA, K.J., FAUSTO, A.M. and MAZZINI, M., 2001. Is cryopreservation a homogeneous process? Ultrastructure and motility of untreated, prefreezing, and postthawed spermatozoa of Diplodus puntazzo (Cetti). Cryobiology, vol. 42, no. 4, pp. 244255. http://dx.doi.org/10.1006/cryo.2001.2328. PMid:11748933.

TIERSCH, T., 1995. Cryopreservation of fish sperm: Laboratory, hatchery and field studies of twenty species. In: F.W.J. GOETZ and P. THOMAS, eds. Proceedings of the Fish International Symposium on the Reproductive Physiology of Fish. Austin: University of Texas AT Austin, pp. 2-8.

VIVEIROS, A.T.M. and GODINHO, H.P., 2009. Sperm quality and cryopreservation of brazilian freshwater fish species: a review. Fish Physiology and Biochemistry, vol. 35, no. 1, pp. 137-150. http://dx.doi.org/10.1007/s10695-008-9240-3. PMid:19189240.

YAO, Z., CRIM, L.W., RICHARDSON, G.F. and EMERSON, C.J., 2000. Motility, fertility and ultrastructural changes of ocean pout (Macrozoarces americanus L.) sperm after cryopreservation. Aquaculture, vol. 181, no. 3-4, pp. 361-375. http://dx.doi. org/10.1016/S0044-8486(99)00240-9.

ZHANG, Y.Z., ZHANG, S.C., LIU, X.Z., XU, Y.Y., WANG, C.L., SAWANT, M.S., LI, J. and CHEN, S.L., 2003. Cryopreservation of flounder (Paralichthys olivaceus) sperm with a practical methodology. Theriogenology, vol. 60, no. 5, pp. 989-996. http:// dx.doi.org/10.1016/S0093-691X(03)00097-9. PMid:12935875. 